\title{
MATA PELAJARAN PKn MELALUI METODE TEAM GAME TOURNAMENT (TGT) PADA SISWA KELAS IX-G SMP NEGERI I STABAT
}

\author{
Erni Nurjani \\ Surel : erni.nurjani.s.pd@gmail.com
}

\begin{abstract}
ABSTRAK
Tujuan penelitian ini adalah Meningkatkan Aktivitas dan Hasil Belajar Siswa. Subjek berjumlah 37 siswa. Hasil obsevasi untuk mengamati aktivitas belajar siswa diperoleh siklus I , kelompok dengan nama "kelompok medan rerata 77\%; kelompok binjai rerata 81,5\%; kelompok langkat rerata 75,3\%; kelompok serdang bedagai 76,2\%; kelompok tebingtinggi $69,7 \%$ dan kelompok karo $71,1 \%$. Pada siklus I belum maksimal untuk dilanjutkan di siklus II dengan perolehan sebagai berikut , kelompok dengan nama "kelompok medan rerata 77\%; kelompok binjai rerata $81,5 \%$; kelompok langkat rerata $75,3 \%$; kelompok serdang bedagai 76,2\%; kelompok Tebing tinggi 78,1,7\% dan kelompok karo 77,8\%. Dari data diatas dapat disimpulkan penerapan metode Team Game Tournament (TGT) pada pembelajaran PKn di SMP Negeri I Stabat dapat meningkatkan hasil belajar dan aktivitas belajar siswa.
\end{abstract}

Kata Kunci: Team Game Tournament, PKn, Hasil Belajar, Aktivitas.

\section{PENDAHULUAN}

Sekolah memiliki peranan dan tanggung jawab yang sangat penting dalam mempersiapkan warga negara yang memiliki komitmen kuat dan konsisten untuk mempertahankan Negara Kesatuan Republik Indonesia. Upaya yang dapat dilakukan adalah menyelenggarakan program pendidikan yang memberikan berbagai kemampuan sebagai seorang warga negara melalui berbagai mata pelajaran termasuk salah satunya Pendidikan Kewarganegaraan. Kemampuan dasar, materi pokok, dan indikator pencapaian hasil belajar yang dicantumkan dalam Standar Nasional merupakan bahan minimal yang harus dikuasai siswa. Oleh karena itu, daerah, sekolah atau guru dapat mengembangkan, menggabungkan, atau menyesuaikan bahan yang disajikan dengan situasi dan kondisi setempat Realitanya hasil belajar siswa dalam materi Pendidikan Kewarganegaraan belum menunjukkan hasil yang diinginkan. Berdasarkan hasil refleksi diri dari pengalaman mengajar pembelajaran Pendidikan Kewarganegaraan di kelas IX-G SMP Negeri 1Stabat Kab. Langkat Provinsi Sumatera Utara tahun pelajaran 2016/2017 diperoleh data sebagai berikut: (1) kegiatan pembelajaran masih banyak didominasi dalam ceramah maupun 

tanya jawab oleh guru dikarenakan siswa kurang aktif mengikuti pembelajaran Pendidikan Kewarganegaraan; (2) metode yang digunakan dalam pembelajaran Pendidikan Kewarganegaraan masih menitik beratkan pada penanaman informasi/konsep-konsep yang dipelajari diberitahukan atau disajikan dengan ceramah saja, sehingga anak merasa jenuh terlihat dari tidak antusiasnya siswa dalam proses belajar mengajar; (3) dalam proses pembelajaran Pendidikan Kewarganegaraan siswa belum bisa diarahkan dalam belajar mandiri.

Dari hasil evaluasi proses pembelajaran di atas ternyata belum memberikan dampak yang baik terhadap peningkatan aktivitas dan hasil belajar siswa. Hal ini disebabkan karena proses pembelajaran yang dilakukan masih menggunakan metode yang kurang menarik perhatian siswa. Sehubungan dengan permasalahan tersebut, maka perlu diadakan tindakan perbaikan-perbaikan sebagai upaya meningkatkan aktivitas dan hasil belajar siswa dalam Pendidikan Kewarganegaraan.

Melihat kondisi tersebut di atas, maka dirasa perlu adanya suatu perubahan baru dalam pelaksanaan pembelajaran PKn di SMP Negeri I Stabat Kab. Langkat agar siswa lebih aktif dan kreatif sehingga bisa berkembang sesuai dengan tingkat kemampuan masing-masing. Dalam usaha untuk meningkatkan keaktifan dan kekreatifan siswa dalam proses pembelajaran bisa dengan menggunakan salah satu model dari pembelajaran gotong royong atau cooperative learning. Model pembelajaran yang diterapkan adalah model pembelajaran team game tournament (TGT), yaitu "Suatu tipe atau model pembelajaran kooperatif yang mudah diterapkan, melibatkan aktivitas seluruh siswa tanpa harus ada perbedaan status, melibatkan peran siswa sebagai tutor sebaya dan mengandung unsur permainan dan reinforcement."

Model pembelajaran team game tournament (TGT) yang merupakan salah satu model dalam pembelajaran cooperative learning merupakan suatu model pembelajaran yang memungkinkan terjadinya hubungan multi arah yaitu hubungan antara siswa dengan guru dan siswa dengan siswa lain di dalam kelompoknya. Oleh karenanya dengan adanya interaksi ini dapat membantu siswa dalam memahami materi yang diberikan dan siswa lebih aktif serta partisipatif dalam proses pembelajaran yang nantinya akan berpengaruh juga dalam hasil belajar mereka.

Model pembelajaran TGT ini sesuai bila diterapkan pada siswa sekolah menengah pertama yang merupakan anak didik usia remaja yang memiliki kecenderungan suka berkelompok dan memiliki kebutuhan akan aktualisasi diri yang tinggi. Hal ini dikarenakan dalam model pembelajaran TGT siswa mempunyai kesempatan untuk bekerja secara berkelompok dan semua siswa dari semua tingkatan 
kemampuan awal memiliki kesempatan yang sama untuk dapat menyumbangkan nilai maksimum bagi timnya. Selain itu, dalam pembelajaran dengan metode TGT ini latihan-latihan soal yang diberikan dikemas dalam bentuk game yang dikompetisikan agar siswa dapat menyumbangkan nilai maksimal bagi kelompoknya agar dapat memenangkan turnamen. Melalui metode pembelajaran kooperatif model TGT ini diharapkan siswa akan termotivasi dalam mengikuti proses pembelajaran PKn. Siswa dituntut untuk aktif dalam kegiatan bermain sambil belajar.

Penggunaan model pembelajaran TGT dimaksudkan untuk mempermudah siswa dalam mengikuti pembelajaran sehingga siswa termotivasi untuk terlibat secara aktif dan tidak merasa cepat bosan dalam mengikuti proses pembelajaran. Berdasarkan uraian tersebut di atas maka peneliti ingin melakukan penelitian tindakan kelas untuk memperbaiki pembelajaran selama ini dengan judul "Upaya Meningkatkan Aktivitas dan Hasil belajar Siswa Mata Pelajaran PKn Melalui Metode Team Game Tournament (TGT) pada Siswa Kelas IX-G SMP Negeri 1 Stabat Tahun Ajaran 2016/2017".

Berdasarkan permasalahan yang telah diuraikan pada latar belakang masalah diatas dapat dirumuskan masalah sebagai berikut:

a. Bagaimana Penerapan metode team game tournament (TGT)
Untuk Meningkatkan Aktivitas Belajar Siswa Kelas IX-G SMP Negeri 1 Stabat Kab. Langkat TP. 2016/2017".

b. Bagaimana Penerapan metode team game tournament (TGT) Untuk Meningkatkan Hasil Belajar Siswa Kelas IX-G SMP Negeri 1 Stabat Kab. Langkat TP. 2016/2017"'.

\section{METODE PENELITIAN}

Subjek pada penelitian ialah berjulah 37 siswa kelas IX-G SMP Negeri 1 Stabat. Selama perbaikan pembelajaran dilaksanakan, peneliti membutuhkan teman sejawat untuk melakukan observer mengamati aktivitas siswa selama proses pembelajaran berlangsung dan mencatat hal-hal yang penting untuk perbaikan pembelajaran. Prosedur perbaikan pembelajaran meliputi kegiatan pelaksanaan penelitian tindakan kelas yang disusun oleh Kemmis dan Mc Targgat yang terdiri dari 4 tahap yaitu perencanaan tindakan observasi dan refleksi, serta pelaksanaan penelitian ini direncana kan 2 siklus.

\section{HASIL PENELITIAN DAN PEMBAHASAN}

Dapat dilihat hasil belajar siswa pada prasiklus diperoleh 8 orang tuntas belajar atau sekitar $21.60 \%$ dan 29 orang atau sekitar $70.40 \%$ tidak tuntas belajar. Hasil dari refleksi yang dilakukan peneliti dengan rekan sejawat yang melakukan observasi ditemukan beberapa kelemahan: 1) metode yang 
SEJ VOLUME 7 NO. 1 JUNI 2017

digunakan yaitu penugasan ternyata siswa banyak yang tidak mengerjakan tugas yang diberikan; 2) ketika guru mengajar dengan metode ceramah terlihat siswa kebanyakan bosan dengan ceramah guru; 3) ketika guru mengajukan pertanyaan siswa tidak menjawab pertanyaan guru, sehingga guru mengambil inisiatif untuk menjawab pertanyaannya. Untuk memperbaiki pembelajaran PKn di SMP Negeri I Stabat maka diterapkan pembelajaran dengan menggunakan metode Team Game Tournament (TGT) pada siklus I.

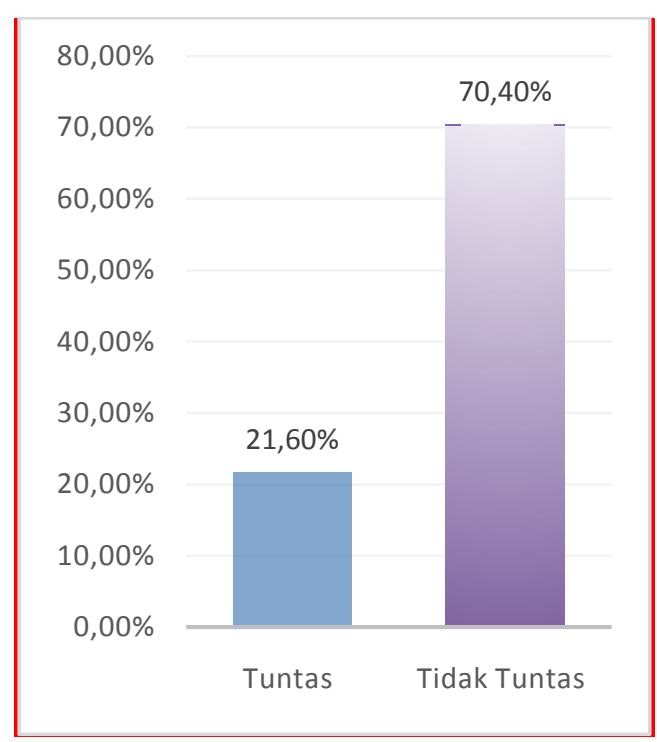

\section{Grafik Hasil Belajar Siswa Prasiklus Mata Pelajara PKn SMP Negeri 1 Stabat}

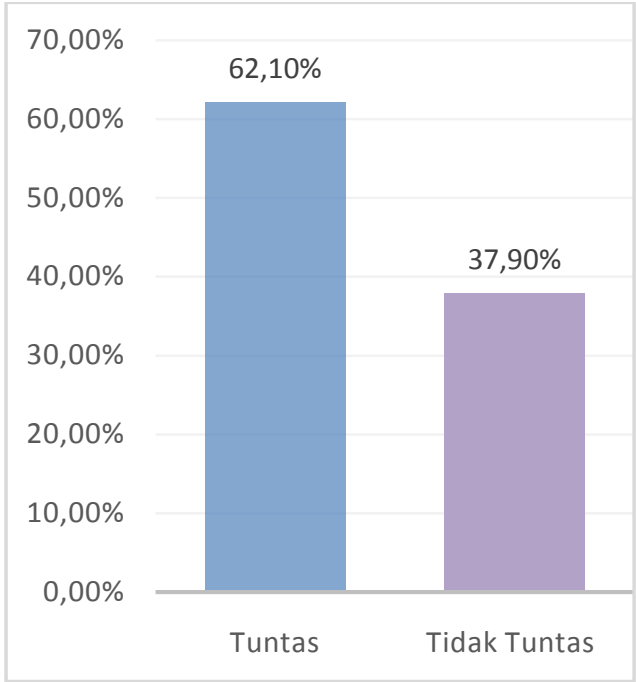

\section{Grafik Hasil Belajar Siswa Siklus I Mata Pelajara PKn SMP Negeri 1 Stabat}

Dari grafik diatas dapat dilihat hasil belajar siswa pada siklus I diperoleh 23 orang tuntas belajar atau sekitar $62,10 \%$ dan 14 orang atau sekitar $37,90 \%$ tidak tuntas belajar. Dari hasil tersebut dapat disimpulkan bahwa pembelajaran diatas belum mencapai ketuntasan belajar secara klasikal untuk itu perlu dilanjutkan ke siklus berikutnya.

\begin{tabular}{|l|l|c|c|c|c|c|c|c|c|c|}
\hline \multirow{2}{*}{ No } & \multirow{2}{*}{ Nama Kelompok } & \multicolumn{6}{|c|}{ Kriteria } & \multirow{2}{*}{ Rerata } \\
\cline { 3 - 10 } & & 1 & 2 & 3 & 4 & 5 & 6 & 7 & 8 & \\
\hline 1 & Medan & 65 & 75 & 77 & 75 & 77 & 65 & 75 & 70 & $72,3 \%$ \\
\hline 2 & Binjai & 67 & 76 & 80 & 77 & 80 & 70 & 82 & 70 & $75,2 \%$ \\
\hline 3 & Langkat & 66 & 75 & 75 & 76 & 76 & 66 & 77 & 66 & $72,1 \%$ \\
\hline 4 & Serdang Bedagai & 65 & 77 & 67 & 75 & 70 & 70 & 70 & 65 & $69,8 \%$ \\
\hline 5 & TebingTinggi & 50 & 75 & 70 & 70 & 75 & 75 & 70 & 73 & $69,7 \%$ \\
\hline 6 & Karo & 55 & 77 & 74 & 75 & 70 & 73 & 75 & 70 & $71,1 \%$ \\
\hline
\end{tabular}

Hasil observasi dalam kegiatan pembelajaran dengan menerapkan metode Team Game Tournament (TGT) dengan target $75 \%$ setiap kriteria dikatakan tuntas yaitu: 1) hasil observasi keberanian siswa 
dalam bertanya dan mengemukakan pendapat masih dibawah target dari ke 6 kelompok tidak ada yang mencapai target; 2) kriteria Motivasi dan kegairahan dalam mengikuti pembelajaran (meyelesaikan tugas mandiri atau tugas kelompok) sudah mencapai target $75 \%$; 3) keseriusan siswa dalam mengikuti turnamen masih ada 3 kelompok yang belum tuntas; 4) Partisipasi siswa dalam pembelajaran (memperhatikan, ikut melakukan kegiatan kelompok, selalu mengikuti petunjuk guru), 1 kelompok yang belum tuntas; 5) Interaksi siswa dalam mengikuti diskusi kelompok 2 kelompok yang belum tuntas; 6) Hubungan siswa dengan siswa lain selama pembelajaran (dalam kerja kelompok), 4 kelompok yang belum tuntas; 7) Interaksi guru dengan siswa dalam pembelajaran, 2 kelompok yang belum tuntas dan; 8) Tanggungjawab siswa di dalam tugas kelompok, 5 kelompok yang belum tuntas . dari data diatas dapat disimpulkan penerapan metode metode Team Game Tournament (TGT) pada pembelajaran PKN di SMP negeri I Stabat pada siklus I hanya satu kelompok yang tuntas.

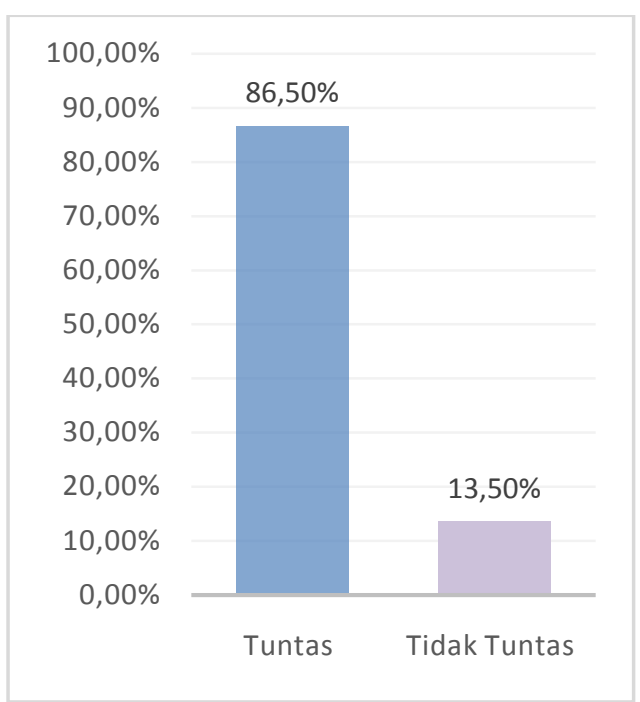

\section{Grafik Hasil Belajar Siswa Siklus II Mata Pelajara PKn SMP Negeri 1 Stabat}

Dari grafik diatas dapat dilihat hasil belajar siswa pada siklus II diperoleh 32 orang tuntas belajar atau sekitar $86,50 \%$ dan 5 orang atau sekitar $13,50 \%$ tidak tuntas belajar. Dari data diatas dapat disimpulkan bahwa pada siklus II pembelajaran dengan menggunakan metode Team Game Tournament (TGT) dapat meningkatkan hasil belajar siswa.

\begin{tabular}{|l|l|c|c|c|c|c|c|c|c|c|}
\hline \multirow{2}{*}{ No } & \multirow{2}{*}{ Nama Kelompok } & \multicolumn{7}{|c|}{ Kriteria } & \multirow{2}{*}{ Rerata } \\
\cline { 2 - 10 } & 1 & 2 & $\mathbf{3}$ & $\mathbf{4}$ & $\mathbf{5}$ & $\mathbf{6}$ & 7 & $\mathbf{8}$ & \\
\hline 1 & Medan & 75 & 75 & 80 & 75 & 77 & 82 & 75 & 77 & $77 \%$ \\
\hline 2 & Binjai & 80 & 80 & 85 & 80 & 80 & 85 & 82 & 80 & $81,5 \%$ \\
\hline 3 & Langkat & 76 & 75 & 80 & 76 & 76 & 77 & 77 & 66 & $75,3 \%$ \\
\hline 4 & Serdang Bedagai & 77 & 80 & 75 & 75 & 77 & 76 & 75 & 75 & $76,2 \%$ \\
\hline 5 & TebingTinggi & 80 & 75 & 83 & 77 & 80 & 75 & 80 & 75 & $78,1 \%$ \\
\hline 6 & Kar0 & 75 & 80 & 80 & 75 & 77 & 83 & 75 & 78 & $77,8 \%$ \\
\hline
\end{tabular}

Hasil observasi dalam kegiatan pembelajaran dengan menerapkan metode Team Game Tournament (TGT) dengan target $75 \%$ setiap 
kriteria dikatakan tuntas dari delapan kriteria obserbasi 7 kelompok tuntas semuanya hanya ada 1 kelompok "langkat" yang tidak tuntas kategori 8) Tanggungjawab siswa di dalam tugas kelompok, namun dari 6 kelompok yang ada jika dirataratakan semua telah memenuhi target.Dari data diatas dapat disimpulkan penerapan metode metode Team Game Tournament (TGT) pada pembelajaran PKN di SMP Negeri I Stabat pada siklus II dapat meningkatkan aktivitas belajar siswa.

\section{Pembahasan}

Penerapan metode Team Game Tournament (TGT) pada pembelajaran PKn pada siswa kelas IX-G SMP Negeri 1 Stabat Kab.Langkat menunjukkan adanya peningkatan ketercapaian indikator kinerja kualitas proses pembelajaran dan indikator kualitas hasil belajar siswa. Hasil akhir siklus II memperlihatkan kenaikan pencapaian target pada tiap aspeknya, bahkan pencapaian secara keseluruhan aspek sudah melampaui target yang ditentukan pada setiap aspeknya. Berikut ini penjelasan ketercapaian target pada setiap aspek hasil belajar dan aktivitas belajar. Hasil belajar pada Prasiklus diperoleh 8 orang tuntas belajar atau sekitar $21.60 \%$ dan 29 orang atau sekitar $70.40 \%$ tidak tuntas belajar; meningkat pada Siklus I menjadi diperoleh 23 orang tuntas belajar atau sekitar 62,10\% dan 14 orang atau sekitar $37,90 \%$ tidak tuntas belajar; dan pada siklus II meningkat menjadi 32 orang tuntas belajar atau sekitar 86,50\% dan 5 orang atau sekitar 13,50\% tidak tuntas belajar. Dari data di atas dapat disimpulkan bahwa pada siklus II pembelajaran dengan menggunakan metode Team Game Tournament (TGT) dapat meningkatkan hasil belajar siswa, sesuai dengan pendapat Khudori, dkk (2012) penerapan metode TGT dapat meningkatkan motivasi dan hasil belajar siswa di SMP Negeri 7 Purworejo.

Hasil obsevasi untuk mengamati aktivitas belajar siswa diperoleh siklus I, kelompok dengan nama "kelompok medan rerata $77 \%$; kelompok binjai rerata $81,5 \%$; kelompok langkat rerata $75,3 \%$; kelompok serdang bedagai $76,2 \%$; kelompok tebingtinggi $69,7 \%$ dan kelompok karo 71,1\%. Pada siklus I belum maksimal untuk dilanjutkan di siklus II dengan perolehan sebagai berikut, kelompok dengan nama "kelompok medan rerata $77 \%$; kelompok binjai rerata $81,5 \%$; kelompok langkat rerata $75,3 \%$; kelompok serdang bedagai $76,2 \%$; kelompok tebingtinggi $78,1,7 \%$ dan kelompok karo $77,8 \%$. Dari data diatas dapat disimpulkan penerapan metode Team Game Tournament (TGT) pada pembelajaran PKN di SMP Negeri I Stabat pada siklus II dapat meningkatkan aktivitas belajar siswa. Sesuai dengan hasil penelitian Moh Fathur Rozi, dkk. 2013. Terbukti dari setiap siklusnya aktivitas siswa dan hasil belajar 
siswa selalu mengalami peningkatan. Pada siklus I aktivitas siswa mencapai $75 \%$, siswa yang masuk dalam kriteria aktif sebanyak 27 siswa. pada siklus II aktivitas siswa mengalami kenaikan sebesar $11 \%$ yaitu mencapai $86 \%$.

\section{SIMPULAN}

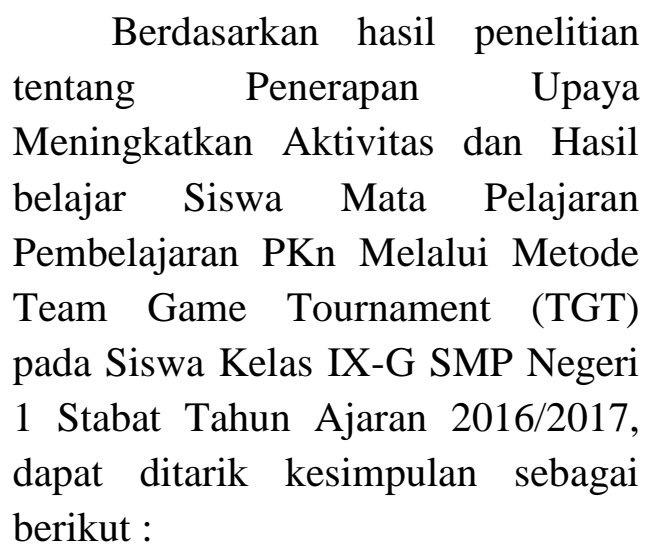

a. Hasil belajar pada Prasiklus diperoleh 8 orang tuntas belajar atau sekitar $21.60 \%$ dan 29 orang atau sekitar $70.40 \%$ tidak tuntas belajar;

b. Pada Siklus I menjadi diperoleh 23 orang tuntas belajar atau sekitar $62,10 \%$ dan 14 orang atau sekitar 37,90\% tidak tuntas belajar;

c. Pada siklus II meningkat menjadi 32 orang tuntas belajar atau sekitar $86,50 \%$ dan 5 orang atau sekitar 13,50\% tidak tuntas belajar.

d. Hasil obsevasi untuk mengamati aktivitas belajar siswa diperoleh siklus I, kelompok dengan nama "kelompok medan rerata $77 \%$; kelompok binjai rerata $81,5 \%$; kelompok langkat rerata $75,3 \%$; kelompok serdang bedagai
$76,2 \%$; kelompok tebingtinggi $69,7 \%$ dan kelompok karo $71,1 \%$.

e. Hasil obsevasi untuk mengamati aktivitas belajar siswa diperoleh siklus II dengan perolehan sebagai berikut, kelompok dengan nama "kelompok medan rerata 77\%; kelompok binjai rerata $81,5 \%$; kelompok langkat rerata $75,3 \%$; kelompok serdang bedagai $76,2 \%$; kelompok tebingtinggi $78,1,7 \%$ dan kelompok karo $77,8 \%$.

\section{DAFTAR PUSTAKA}

A.M. Sardiman. 2011. Interaksi dan Motivasi Belajar Mengajar. Jakarta: Rajawali.

Dimyati dan Mudjiono. 2006. Belajar dan Pembelajaran. Rineka Cipta: Jakarta.

Faridy, MS. 2009. Pendidikan Kewarganegaraan Untuk SMP/MTS. Kelas IX. Pusat Perbukuan Departemen Pendidikan Nasional. Di unduh dari Buku Paket.com

Hanafiah, Nanang \& Cucu Suhana. 2010. Konsep Strategi Pembelajaran. Bandung: Refika Aditama.

Istigomah. 2006. Metode-metode Pembelajaran. Jakarta: Pustakan Panjimas

Nasution, S. 1997. Berbagai Pendekatan dalam Proses Belajar Mengajar. Jakarta: Bumi Aksara.

Robert E. Slavin. 2010.Cooperative Learning: Teori, Riset dan 
SEJ VOLUME 7 NO. 1 JUNI 2017

Praktik. Bandung: Nusa Media

Sugihartono, dkk. (2007). Fisikologi Pendidikan. Fakultas Ilmu Pendidikan. Universitas Negeri
Yogyakarta. Yogyakarta. UNY Press.

Sujana, Nana . 2005. Dasar-dasar Proses Belajar Mengajar.

Sinar Baru Algesindo:

Bandung. 